\title{
THE CREATIVE ROLE OF THE JUDGE: RESTRAINT AND FREEDOM IN THE COMMON LAW TRADITION
}

\author{
By GHARLES E. GLARK $f$ and DAVID M. TRUBEK $f \dagger$
}

\section{Introduction}

It is hard to realize that forty years have passed since Judge Cardozo gave his famous lectures on The Nature of the Judicial Process at Yale and achieved at once national fame as well as that idolatrous regard of the law schools which eventually propelled him to the highest court of the land. Elsewhere the senior author has recorded his reactions as a cub of the Yale Law faculty in joining in the invitation to the then essentially unknown judge and of noting the instant reaction of his hearers which incidentally led to their shifting from the smallest lecture room (as originally planned) to the largest on the campus. ${ }^{1}$ These lectures of 1921 and their successorsThe Growth of the Law, The Paradoxes of Legal Science ${ }^{2}$-have now become so much a part of all legal thinking as to the judge's task of decision that reference to the originals is likely to be thought no longer necessary. But a rereading of these great monographs gives a sense of renewed life, of complete modernity, to their central thesis. And a strange recrudescence in legal literature of the thesis that judges must find or restate, and not make, law suggests that every generation must rediscover these truths for itself. We have been forcibly reminded of this recurring need by a promise to the editors of the Journal to review an important new book by Karl Llewellyn, brilliant legal philosopher and number one legal realist-a guild of which Cardozo was at least godfather-intriguingly entitled The Common Law Tradition: Deciding Appeals. ${ }^{3}$ If, as we fear, this otherwise sprightly book has omitted or at least slighted a major, if not climactic, part of Cardozo's teaching, then it is all the more rewarding to return to the master's words often and with due humility and attentiveness. So while this article is primarily a book review of the latest essay in this field, we have found it quite naturally becoming a tribute to Cardozo himself.

fUnited States Circuit Judge; former Dean and Sterling Professor of Law, Yale Law School.

HYale LL.B., 1961; Note and Comment Editor, Yale Law Journal, 1960-61; Law Clerk to Judge Clark, 1961-62.

1. Clark, State Law in the Federal Courts: The Brooding Omnipresence of Erie v. Tompkins, 55 Yale L.J. 267 (1946), reprinted in JURISPRUdENCE IN ACTTON 53 (1953).

2. Cardozo, The Nature of the Judictar Process (1921); Cardozo, The Growth of the Law (1924); Cardozo, The Paradoxes of Legat Science (1928), reprinted in Selected Writrings of Benjamin Nathan Cardozo (Hall ed. 1947).

3. Llewellyn, The Common Law Tradition: Deciding Appeals (1960) [hereinafter cited as LLEWEILIXN]. 
It is well to recall the way in which Cardozo develops his subject. He began, "The work of deciding cases goes on every day in hundreds of courts throughout the land."4 Then he proceeded to isolate and define in separate lectures certain methods of decision: the rule of analogy or the method of philosophy; the method of evolution along the line of historical development; the method of tradition along the lines of justice, morals, and social welfare, the mores of the day; and the method of sociology or "the judge as a legislator." In an illuminating article on Cardozo's Philosophy of Law, Professor Patterson has restyled these methods rather more aptly, but still strictly in the Cardozo meaning, as the methods of logic, of history and precedent, of custom or tradition, and of social values. Cardozo then proceeded not merely to define and distinguish these methods, but to appraise broadly the extent of their use in actual practice. Thus he recognizes the predestined outcome of most cases, which he first estimated at a "majority," and then later at "nine-tenths, perhaps more," of the cases that come before a court. ${ }^{7}$ But in the statistically few, though important, original cases presenting novel issues, it was undoubtedly the last method, in which the judge must stand alone as legislator, that was outstandingly important. ${ }^{8}$ This would seem to be as it should be; for these are the cases which are the (legal) world shakers, the cases to be remembered and cited and recited by judges and lawyers to shape the law of the the future, and at the same time they are cases in which the authoritative guides are weakest.

Llewellyn's book recognizes judicial creativity as part of the common law tradition, but seems at the same time to reject the notion of judicial freedom which was the starting point for Cardozo's fourth method of decision -the method of social value, or the judge as a legislator. In doing so, he has apparently overlooked a factor which Cardozo found important-the impact of judicial subjectivity on the process of decision. And so notwithstanding all the worth we find in the volume, we feel a responsibility to state some of the questions we have about Llewellyn's method, and especially about his reduction of judicial freedom to the job of exposition strictly "in the common law tradition."

4. Cardozo, The Nature of the Judictal Process 9 (1921).

5. Id. Lectures I, II \& III. See especially id. at 30-31.

6. 88 U. PA. L. Rev. 71, 156, 160-65 (1939). See also Patterson, Foreword to SELECTEd WRITINGS, op. cit. supra note 2 , at $\mathrm{v}$, ix.

7. The first is from Cardozo, The Nature of rhe Judicial Process 164 (1921); the second is from Cardozo, The Growth of the LaW 60 (1924), quoted in Llewelly at 25 , giving some similar statistics from other sources. Judge Clark, in a subjective test covering 300 appeals on which he has sat during the last two years, found clear one-way cases comprised at least $70 \%$, while around $10 \%$ were highly original cases giving scope to the method of social values. In the remaining $20 \%$, the outcome actually proved certain, but counsel might be forgiven for thinking they had a bare chance of success.

8. Cardozo, The Nature of the Judictal Process, Lecture III (1921). See Patterson, Cardozo's Philosophy of Law, 88 U. PA. L. REv. 71, 88 (1939). 
It is not possible within the confines of a single article to give a balanced review of all the wide range of ideas distilled from a lifetime's thinking of one of the most fertile minds of our generation and here captured in sumptuous book form. Nor can we now attempt a full appraisal of the author's thought. We have simply attempted to chart his image of the process of judicial decision in the areas of judicial creativity. This review will therefore focus on the following questions:

How does Llewellyn believe a court frames a rule of law when authority permits such creativity?

Has Llewellyn overlooked a vital aspect of the judicial process, namely, the personal outlooks, values, even bias, of the individual judge?

Because Llewellyn himself has said that ". . . the dignity and measure of a critic ... lie in that he sees the record whole,"9 let us make a sincere attempt toward a balanced approach. For it is to be frankly admitted that in many aspects the book is magnificent. Such things as the Theory of Rules, the catalogue of precedent techniques, the notions about appellate advocacy, are in Edmond Cahn's apt word truly useful. ${ }^{10}$ There are gems of legal wisdom, such as his famous article, here reprinted, ${ }^{11}$ Canons on Statutes, showing how each epigrammatic canon of statutory interpretation is offset and deflated by another canon of opposite tenor. There is the wise admonition-perhaps too optimistically regarded as now only an infrequent bygone trend, rather than an inveterate judicial escape-against "the hinging of a reversal on one or three narrow points of technical procedure, without serious inquiry into their reasonably possible net effect."12 And there is the whole original trend of research into what appellate courts are actually doing in their decisions, with the further suggestion (one dear to our hearts ${ }^{13}$ )

9. LLEWELLYN at 397.

10. As quoted on the dust jacket of the book; elsewhere he describes it as the "Most Important Book of the Year." Cahn, Jurisprudence, in 1960 ANNUAL SURveY of AMrRICAN LAw 587, 599 (1961). The reviews have all been most flattering; indeed, except possibly for Professor Kurland's gently astringent piece in $A$ Teacher's View, 28 U. CHI. L. REv. 580 (1961), they have been quite wildly enthusiastic. Dean Prosser, for example, calls it "a masterpiece, and a most extraordinary one." Prosser, Book Review, $13 \mathrm{~J}$. LEGAL ED. 431 (1961). See also Desmond, Book Review, 36 N.Y.U.L. Rev. 529 (1961) ; Madden, Book Review, 10 Catholic U.L. Rev. 100 (1961); Waterman, Book Review, 46 A.B.A.J. 1213 (1960) ; Breitel, Lasswell \& Westwood, Book Review, 61 Conum. L. Rev. 931, 940, 948 (1961) ; Friendly, Levy \& Shestack, A Symposium, 109 U. PA. L. Rev. 1040, 1045, 1051 (1961); Schaefer, McGowan \& Kurland, Book Review, 28 U. CrI. L. Rev. 574, 576, 580 (1961). As appears, it has become customary to approach the work with batteries of three; but that, we are told, is to be stepped up to five and to a whole issue. $45 \mathrm{~J}$. AM. JuD. Soc'y 70 (1961).

11. Llewellyn at 521, from 3 VANd. L. REv. 395, 401 (1950).

12. LLEWELLYN at 283.

13. Advanced in Clark, Fact Research in Law Administration, 2 Cons. B.J. 211 (1928), reprinted in Clark \& Shulman, A Study of Law Administration in Connecticut 203, 204 (1937). 
of the mine of sociological data to be found in the reports of court activity. The book at times is exciting reading. Llewellyn's deep faith in the grandeur of the Law and her practitioners ennobles all of us. In its Gothic encrustations the book reminds one of a great cathedral, whose very structure is the lack of a mechanical plan. It has a sense of organic growth and is infused with a passionate faith. Perhaps, too, like the great Westminster Abbey, it has grandeur, and yet lacks a unifying central spire. With these words of praise let us proceed to evaluate the author's thesis.

\section{The Book's Thesis: Reckonability through Sense}

The book is explicitly aimed at what the author calls a crisis in the bar's confidence over the work of our appellate courts. This crisis has arisen because of widespread doubt as to whether "there is any reckonability in the work of our appellate courts, any real stability of footing for the lawyer, be it in appellate litigation or in counseling, whether therefore there is any effective craftsmanship for him to bring to bear to serve his client and to justify his being."14 Llewellyn's answer to this question is Yes-a carefully defined, but unquestionable, hearty Yes.

A prime difficulty for us in reviewing the book is our complete skepticism as to whether any such crisis exists. Of course there is now-as always in our history-criticism of the Supreme Court in its exercise of its governmental and political powers and responsibilities. But Llewellyn quite properly puts that special case to one side. Elsewhere we see no such widespread disillusionment with the courts as he notes. On the contrary, the traditional excessive confidence in the courts to decide everything continues ${ }^{15}$; and even the present popular stress on heavy dockets and congestion is geared to give the courts more help and to free them from intolerable burdens the better to do their work. The unfortunate consequence here seems to be that Llewellyn is straining desperately to prove a thesis in order to offset a crisis which does not exist.

In reaching his affirmative answer to the question whether decisions are reckonable, Llewellyn must delve deeply into the judicial process. He has studied, at great length, the reports and advance sheets, and attempts to trace the style and manner of today's appellate deciding. The book is deeply concerned with the way cases are decided.

The starting point of the study is the observation that the rules of law alone do not decide cases. He does not need to prove this point with great care, for the groundwork has already been laid down by the Legal Realists. ${ }^{10}$

14. LLEWELLYN at 3-4.

15. See Clark, The Dilemma of American Judges: Is Too Great "Trust for Salvation" Placed in Them?, 35 A.B.A.J. 8 (1949). Compare Hamilton, The Judicial Process, 8 ENcyc, Soc. Scr. 450 (1932), quoted note 55 infra.

16. Llewellyn, On Reading and Using the Newer Jurisprudence, 40 ColuM. L. Rev. 581 (1940); see also LLEWELLYN at 181. 
What Llewellyn does contribute to this observation is an excellent discussion of the "Leeways of Precedent." He has collected "A Selection of Available Impeccable Precedent Techniques" which includes sixty-four possible ways to use precedent. ${ }^{17}$ They vary from "following" through "expansion and redirection" to "avoidance." These are techniques in daily use, and most are acceptable to all law-craftsmen. Not only does this selection provide judges and advocates with a ready-made tool kit for use in daily practice; it also persuasively demonstrates that courts are not controlled or dictated by prior authority.

He finds, on the contrary, that the law is in motion, that courts are constantly creating the law. As did Cardozo, he realizes that perfectly legitimate use of standard legal tools often leaves the judge with a choice which calls for the excercise of judicial creativity. Unlike Cardozo, who found this choice in a statistically small number of cases, Llewellyn stresses the presence of the creation-potential in almost all cases: "The little case, the ordinary case, is a constant occasion and vehicle for creative choice and creative activity, for the shaping and on-going reshaping of our case law."18

This creative activity and the forces that guide and channel it form the main subject-matter of the book. Llewellyn believes that judicial creation, albeit present in the mine-run of cases, does not lead to arbitrary or unreckonable decisions. Rather, it responds to the existing body of authoritative doctrine, ${ }^{10}$ and a lawyer who knows how to read this body of doctrine can "eight times out of ten" predict the outcome of an appeal.

One factor which convinces Professor Llewellyn that the law grows along discernible lines is his discovery that in a major portion of decided cases appellate courts base their holding on an unqualified citation to prior authority. His samples of recent decisions lead him to conclude that these citations are usually accurate, but that in 30 per cent of the cases studied the citation was to a prior ruling that was not in strict terms a holding. ${ }^{20}$ From this he concludes that the courts are building, are creating, but that they are able to do this within bounds set by available doctrine.

The chief reason for this development, he states, is that courts have rediscovered the Grand Style of appellate work which prevailed in the first 50 years of our Republic. There are many other controlling factors which Llewellyn lists as "steadying" the appellate courts-among them the lawconditioning of the judges, the written opinion, known doctrinal techniques, group decision, and the like. But it is clear that it is the return to the Grand Style which, for Llewellyn, is the real key to reckonability in our courts today.

The earlier Grand Style was practiced by such men as Marshall, Kent, Cowen, in the United States, and Mansfield in England. ${ }^{21}$ This judicial style

17. LLEWELLYY at 77-91.

18. Id. at 99.

19. Id. at 190-91.

20. Id. at 103 .

21. Id, at 36-41. 
viewed precedents "as welcome and very persuasive," but tested precedent against three types of reason: (1) the reputation of the opinion-writing judge, (2) "principle"- - a broad generalization yielding sense and order-and (3) "policy" or the consequences of the rule. This style is reviving in the United States in the past 20 years, Llewellyn finds; and it is the surest device known to insure reckonability without sacrificing the duty to Justice. For rules of law framed under this style have a vitality that other rules of law do not, and this vitality is itself a check on judicial creation.

The details-and there are plenty-of this theory are beyond the scope of this article. For the purpose of this study we must jump to Llewellyn's description of how rules of law are made in the Grand Style. For it is in his description of how courts, operating on these principles, decide cases that his image of the judicial process emerges.

At this point one should whisper to the reader that he is not to be deceived by the word "description." For Llewellyn is not simply telling courts how they do decide cases; he is also telling them how they should decide these cases. And we must judge him as a maker of rules, not simply as a detached observer.

\section{How Rules Are Made: Herein of Situation-Sense, Type-Situation and Other Hyphen-Concepts}

Authority means much more for Llewellyn than the "rules of law" did to the judges of the late 19th, early 20 th century--era of the "formal style." We imagine these jurists stretching and squeezing the situations that confronted them to fit the corset of correct doctrine; unwilling to shape and adjust the authorities to fit notions of reasonableness, or at least, if that is what they did, unable to admit that that was what they were about. Not so the judge of the Grand Style; for while he is alert to the spirit of the authorities, he is not held back by their letter. Authority in Llewellyn's system is built by courts aware of the fact situation underlying a case, explicitly connecting the rule of law, by reason, to that situation. It is because authority is so created that Grand Style judges can stick within its confines, yet adjust to changing circumstances and a multiplicity of case situations.

The force behind the creation of such authority is the exercise of that strange Ilewellynian faculty, "situation-sense." In his view the great jurists of the past and increasing numbers of contemporary judges rely on a sense of the "type-situation" in a case to aid them in framing and interpreting rules of law. This "situation" is not the "fireside equities" of the case, e,g., that widows always win if they sue railroads; it involves the broader, more generalized aspects of whatever human, commercial, or institutional relationships are at stake.

It is extremely difficult, indeed, to pin down precisely what Llewellyn means by "type-situation" and "situation-sense." The discussion of these concepts is couched in a flowery, transcendental language at times beautiful, at times 
just infuriating. He relies on hyphen-words to communicate vital thoughts: "life-reason," "life-essence," "rule-type," to name just a few. ${ }^{22}$ The communication is imperfect.

For example, he points out that the exercise of "situation-sense" depends in the first instance on definition of the "type-situation." The rule for choosing the problem- or type-situation is as follows:

“. . . 'the' problem-situation extends as far as you are perfectly clear, in your own mind, that you have grasped the picture fully and completely in life-essence and in its detailed variants, and therefore know it to present a significantly single whole, and one over which your knowledge and judgment have command."23

The passage is certainly murky. It keys the whole analysis of the "typesituation"-which in turn is the foundation for the exercise of the highlyvaunted "situation-sense"-on a concept as vague as "life-essence." What is perhaps even more significant is that the whole definition of type-situation reeks of subjectivity; it obviously relies on the individual judge's feel of the facts. Now such a subjective description may be an accurate picture of the process as it works; and perhaps the vast generalization involved in the notion of a type-situation, which must spread over an infinitude of fact situations, cannot be more precisely drawn. But this vague, subjective principle is the keystone of a system which is the antithesis of the subjective, a system which, as Llewellyn constantly stresses, overrides the subjectivity of the individual judge. ${ }^{24}$

Once the court has felt its way toward the "type-situation," it can apply "situation-sense" to choose among the myriad possible paths which the acceptable techniques for handling precedent leave open. What is this sixth sense of the judiciary? For Llewellyn it seems to be an instinctive insight for The Right Rule in a given situation.

22. The index of The Common Law Tradition contains the following unique or specially used hyphenated words :

opinion-kernel
situation-sense
craft-ideals
craft-tradition
period-style
rule-improvement
horse-sense
$\quad$ (sometimes horse sense)
law-conditioned
law-government

type-situation premise-revision craft-controlled rule-type doctrine-conditioned authority-leeways justice-drive craft-practice fact-observations

The text will yield the reader many more; e.g., life-essence, life-wisdom.

23. Llewellyn at 427.

24. Llewellyn, perhaps sensing this criticism of his attempt to build a rule for the "typesituation," finds comfort in the observation that the "craft-tradition" will harness deviants. $I d$. at 214. But is he not invoking the tradition to protect against abuse of one of the factors which itself creates the tradition? 
This faith that there is an "immanent law" in each situation, and that judges have a unique capacity to discover it, infuses The Common Law Tradition. Llewellyn returns repeatedly to a quotation from Levin Goldschmidt which is introduced in the course of the first discussion of "situationsense."25 Because it is a central tenet of his scheme, it is worth reproducing in full :

"Every fact-pattern of common life, so far as the legal order can take it in, carries within itself its appropriate, natural rules, its right law. This is a natural law which is real, not imaginary; it is not a creature of mere reason, but rests on the solid foundation of what reason can recognize in the nature of man and of the life conditions of the time and place; it is thus not eternal nor changeless nor everywhere the same, but is indwelling in the very circumstances of life. The highest task of law-giving consists in uncovering and implementing this immanent law."20

"Situation-sense" is at once the instinct for and the search for this "immanent law."27 At times Llewellyn shows such faith in this "sense" that he says that "sense" itself will propel the court toward a reckonable, "forefeelable" rule; that sense will shape and form the rule. ${ }^{28} \mathrm{He}$ recognizes that courts can imperfectly grasp the sense of the situation or not grasp it at all; in these cases the magic spell is broken and there is no telling what rule will emerge. ${ }^{29}$ Moreover, he indicates that at times reasonable men can differ over what is "sense" and that this concept alone does not mean that reader and court, or Llewellyn himself and the court, will agree on the right rule $; 0$ this despite the belief in an "immanent" law, constantly reiterated, constantly stressed.

\section{Situation-Sense as Common Sense}

Is this the stuff that either Realism or realism is made of? Nowhere in this vast book does Llewellyn give precise, operational indications of how a judge should exercise sense, situation sense, or whatever sense it is that leads toward the immanent law. Yet he tells the judge, again and again, that he, the judge, and he alone, possesses this capacity to sense the correct resolution of the tangled human problems which come before him. And while

25. The index lists 7 direct references to this dictum. But this does not indicate the actual number of times the concept is used, since it is indexed only when it is referred to as Goldschmidt's Immanent Law, rather than the immanent law. References to the latter are legion.

26. Llewellyn at 122, quoting from Goldschmidt, Preface to KrITIK Des ENTwUrfs

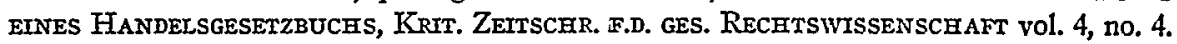
We fear that not many of us know "that amazing legal historian and commercial lawyer, Levin Goldschmidt." Ibid.

27. Llewellyn at 261, 270, 271.

28. Id. at 127, 157, 190.

29. Id. at 127-28.

30. Id. at $139,224$. 
he occassionally wavers, the author repeatedly reiterates his faith in the ability of the average judicial officer, following the Grand Style, to sense the situation and grasp the immanent law.

As a matter of description of the thought patterns of individual judges, pressed for time, with average aid from counsel, this may be a fairly accurate picture. It is true that many very good judges may often act in about the way Llewellyn describes; they "size up" the situation and decide what rule it demands. This is the "judicial hunch" or "judgment intuitive" made famous by Judge Hutcheson. ${ }^{31}$ As a question of how things are, these rules and theories have at least surface accuracy for the humdrum run of the many appeals destined to obvious failure.

It seems strange, however, that a "realist" should rest on such a surface description, let alone offer this as a statement not only of how things are, but also of how they ought to be. Even though judges do decide cases on their instinct for the "rightness" of the thing, this fact cannot support the objective control-system Llewellyn is advancing. $\mathrm{He}$ does not say "this is what judges think they do"; rather, he asserts that this is objectively how they act. The immanent law is not, for him, the hypostatization of a subjective preference; it is a working principle and, indeed, a principle which can be grasped only if the judge reaches beyond subjectivity. And it is a principle which, so he holds, is actually grasped and applied by good judges.

Does not this faith in an immanent law, to be grasped by that sixth judicial "situation-sense," obscure the impact of the judge's personal values and outlook, or what may be the same thing, of societal values as the individual judge perceives them, on the exercise of judicial creativity and the concomitant formation of legal rules? Does not this transcendental approach cloud over a vital part of the judicial process, the one so eloquently developed by Cardozo in his third lecture on the judge as a legislator?32 Llewellyn constantly rejects consideration of the individual judge, feeling that the many checks and controls of the job wash out individual bias. (Paradoxically, his great judges are just those men who could and did influence a whole court to follow their views.) But ultimately in the original or new case must we not come back to that individual bias or inner conviction?

In developing his thesis Llewellyn mentions often the "creative" activity or function, indeed "the creation" of the judge; but in context, these remarks seemed almost apologetic, passing thoughts. ${ }^{33}$ For Llewellyn has divorced "creativity" from the hard choice of values, and the freedom to choose among them, which is an important part of creativity. And in attempting to separate

31. Hutcheson, The Judgment Intuitive: The Function of the "Hunch" in Judicial Decisions, 14 Cornell L.Q. 274 (1929), reprinted in Hutcheson, The Judgrent INturtrve (1932). See also Hutcheson, Lawyer's Law, and the Little, Small Dice, 7 Tur. L. REV. 1 (1932).

32. Cardozo, The Nature of the Judicial Process $98-141$ (1921).

33. See, e.g., LlewellyN at $80,99,106,223,237,325,331$. 
the lessons of his study from the need to make such hard choices, he ducks a more direct attack on grounds which seem rather evasive. In speaking of "the days when useful State statutes were being smacked down" by the Supreme Court, he observes: "I find it difficult to remember who, among my States' Rights friends, was then being worried about the Supreme Court's trespassing." Then he tempers the bite of this observation by adding: "But that goes to substance. The lessons of this study go to manner and method." 34 How can such a dichotomy be found in an area where manner and substance are so intermixed?

In one place, and in one place only, this aspect of the judicial process breaks through discussion of "sense" and "reason" and shouts, in italics, the truth elsewhere suppressed. In his brief discussion of the United States Supreme Court, Llewellyn points out that constant scholarly attention to the operations of the Court over the years has "led the skilled observer into that more refined and accurate understanding of the impact 'of the times,' or 'of public opinion,' or 'of social need,' or 'of justice,' the impact by way of the eyes and knowledge and values and insight of the individual Justices individually $A N D$ of the Court corporate which [understanding] used to be reserved for such ideas as 'prejudice,' 'pigheadedness,' or broad, vague, and not too useful whole-outlook concepts such as 'liberal' or 'conservative." "35 Surely, the nature of the Supreme Court's work and the impact of its decisions may make these factors ever so slightly more significant to its work than to the "mine-run" work of the state courts which are Llewellyn's subjects. But that does not mean that these very factors, these individual forces, are not extremely important in the day-to-day operation of an appeals court. Good lawyers know this; and so does the author of The Common Law Tradition, for he recognizes it implicitly elsewhere. But never does he discuss or analyze it.

The impact of an individual judge's values and outlook on the well-documented creative growth of the law is too important a factor to be omitted from a balanced study of their work. By so omitting it, Llewellyn has masked from layman and lawyer, and from the judge himself, one of the most volatile factors in deciding appeals. He has created an image of the judicial process which suggests that if the judges play the game they will automatically reach the right results. Is he not guilty of shielding the judge, by an obscuring transcendental faith in "sense" and the tradition, from the hard responsibilities of his creative freedom?

\section{The Missing Spire-Iudicial Subjectivity}

Why has Llewellyn overlooked or underplayed the hard facts of judicial subjectivity? The obvious answer is that he may feel that it is a factor which works against his central thesis-the reckonability of appellate decisions. Of

34. Id. at 386.

35. Id. at 391 . 
course this is not precisely true, for a good lawyer can calculate the impact of an individual judge's outlook on his chances of prevailing-and Llewellyn realizes this. No, the roots go much deeper. An earlier article may offer some answers. Writing in 1940, Llewellyn foreshadowed the study that has emerged as The Common Law Tradition, and outlined its goals. ${ }^{36} \mathrm{He}$ started from the recognition that lay at the heart of Realist thought: that the rules of law do not alone decide cases. He expressed then his belief, so central to the thought of The Common Law Tradition, that the essence of a legal system is that its judges are not free to do what they choose or decide what they choose, and that they must be "guided by something independent of the individual preferences or vagaries." 37 If the so-called rules of law don't do it, something must. ${ }^{38}$ It is the discovery, or the creation, of that something else to which The Common Law Tradition is devoted. Perhaps it is because judicial subjectivity wars with this ideal that he has chosen to give it so little a part in his system.

It is on this point that Cardozo seems to be so much more the "realist." $\mathrm{He}$, too, shared the ideal of the creative judge whose freedom was exercised within the bounds of a tradition:

"This judge, even when he is free, is still not wholly free. $\mathrm{He}$ is not to innovate at pleasure. He is not a knight-errant, roaming at will in pursuit of his own ideal of beauty or of goodness. He is to draw his inspiration from consecrated principles." 39

But unlike Llewellyn, he explicitly recognized that this can only be an ideal, and that the reality of things wars constantly with the ideal. The method of sociology, or of social values, his rather more sophisticated analogue of Llewellyn's "situation-sense," was a method of determining the values of society and of applying them to shape the law. Where the judge's values and those prevailing in society clashed, the judge must in theory give way to the "objective right." In practice, however, Cardozo recognized that this would be extremely difficult. The complex and competing values in a case do not come to the judge neatly labeled "society," on the one hand, and "my own" on the other. The judge appraises the social good by his own light: "The perception of objective right takes the color of the subjective mind." 40 It is this reflection on the limits of the human condition, woven into the stuff of Cardozo's thought, that is so patently absent from Llewellyn's scheme.

There is an air of sadness, nay, tragedy, in Cardozo's discussion of the reality of judicial perception of the "good" and "true." And it is communicated with such felicity, and remains so important today, that it seems an appropriate

36. Llewellyn, On Reading and Using the Newer Jurisprudence, 40 CoLun. I. Rev. $581(1940)$.

37. Id. at 583 .

38. Id. at 594 .

39. Cardozo, op. cit. supra note 32, at 141.

40. Id. at 110 . 
tribute on the fortieth anniversary of the famous lectures on The Nature of the Judicial Process to reprint some of these passages:

There has been a certain lack of candor in much of the discussion of the theme, or rather perhaps in the refusal to discuss it, as if judges must lose respect and confidence by the reminder that they are subject to human limitations. I do not doubt the grandeur of the conception which lifts them into the realm of pure reason, above and beyond the sweep of perturbing and deflecting forces. None the less, if there is anything of reality in my analysis of the judicial process, they do not stand aloof on these chill and distant heights; and we shall not help the cause of truth by acting and speaking as if they do. The great tides and currents which engulf the rest of men, do not turn aside in their course, and pass the judges by. ... 'The judges of the nation,' says Montesquieu, 'are only the mouths that pronounce the words of the law, inanimate beings, who can moderate neither its force nor its rigor.' ... It has a lofty sound; it is well and finely said; but it can never be more than partly true. . . . the ideal is beyond the reach of human faculties to attain. ${ }^{41}$

and again:

But every day there is borne in on me a new conviction of the inescapable relation between the truth without us and the truth within. The spirit of the age, as it is revealed to each of us, is too often only the spirit of the group in which the accidents of birth or education or occupation or fellowship have given us a place. No effort or revolution of the mind will overthrow utterly and at all times the empire of these subconscious loyalties. ${ }^{42}$

These quotations, necessarily wrenched from the tone of their context, do not grasp the whole thought or the feeling, but they may suggest it. Having said these things Cardozo goes on to affirm his faith in the system and the tradition, despite the vagaries of subjectivity. But it is an affirmation tinged by the recognition of limits, and by deep humility in the face of those limits. ${ }^{43}$

41. Id. at 167-69.

42. Id. at 174-75; see also the following passage:

There is in each of us a stream of tendency, whether you choose to call it philosophy or not, which gives coherence and direction to thought and action. Judges cannot escape that current any more than other mortals. All their lives, forces which they do not recognize and cannot name, have been tugging at them-inherited instincts, traditional beliefs, acquired convictions; and the resultant is an outlook on life, a conception of social needs, a sense in James" phrase of "the total push and pressure of the cosmos," which, when reasons are nicely balanced, must determine where choice shall fall.

Id. at 12 .

43. Id. at 172. Of course many since Cardozo have pointed out the role of judicial subjectivity in adjudication. A good statement is that of Braden, The Search for Objectivity in Constitutional Lawe, 57 YALE L.J. 571, 594 (1948), quoted in Clark, Federal Procedural Reform and States' Rights; To a More Perfect Union,-Texas L. Rev.-(1961). See also J. Frank, Modern and Ancient Legal Pragmatism-John Dewey \& Co. vs. Aristotle, 25 Notre DaMe Law. 207, 460 (1950), quoted in Cahn, Jerome Frank's Fact-Skepticism and Our Future, $66 \mathrm{Y}_{\mathrm{ALE}}$ L.J. 824, 828 (1957); FRANK, CourTs on Trial 187-89, 370-72 and 


\section{The Great Quest for Certainty}

It was perhaps Cardozo who first pointed out that the movement we have come to call Legal Realism was, despite its more extreme adherents or the occasional brash statements of its more uninhibited followers, a quest for legal certainty..$^{44}$ The movement emerged in a time when the prevailing notions of legal order were gradually being eroded by a series of hydraulic pressures. The older verbal formulas- "the rules of law decide cases"-could not survive in the philosophical climate of the period; a climate which, in Morton White's term, was marked by a "revolt against formalism." 45 The sheer weight of precedent—often conflicting-which flooded the Reports tended to undermine faith in stare decisis. ${ }^{46}$ Perhaps the most significant factor, however, was the great pressure for change brought upon the legal system by a rapidly changing society. When external events demanded a rapid shift from outmoded principles, it became necessary for lawyers to frame principles which would permit them to depart from the pre-existing rules of law without sacrificing the certainty which they had once believed inherent in the more mechanical forms of stare decisis. One of the chief aims of the legal realists was to destroy the false certainty of the other doctrine, a certainty grounded on myth, so that a new, more fundamental certainty could be discovered. ${ }^{47}$ Llewellyn himself has never lost sight of the ultimate goal, an era of true, rather than illusory, certainty, suggested by the threadbare cliche "a government of laws, not men," a cliché which he rejects, offering as a substitute description of the era of true certainty, his phrase, "government by law." 48

This "quest for certainty" on a newer, higher plane infuses Llewellyn's work. And it appears today again and again in the law reviews. The senior author has had occasion to comment on this recent development elsewhere, and to point out the dangers of seeking certainty where it does not exist. ${ }^{49}$ The discussion in the reviews has centered around the Supreme Court, but its import goes beyond that august body. We are speaking here, of course, of the

passim (1949); and the direct replies to the recent Harvard approach cited in note 50 infra. For yet more generalized statements, see Friedmann, Legal Philosophy and Judicial Lawmaling, 61 Coluar. L. Rev. 821 (1961), and Wasserstrom, The Judicial Decision (1961). For the more restricted English concept see Evershed, The Judicial Process in Twentieth Century England, 61 CoLus. L. Rev. 761 (1961).

44. Cardozo, Jurisprudence, in Selected Writings of Benjamin Nathan Cardozo 7, 9 (Hall. ed. 1947) ; Llewellyn, On Reading and Using the Newer Jurisprudence, 40 CoLuA. L. REv, 581 (1940).

45. White, Social Thought in Axrerica; The Revolt Agatnst Foraralism passim (1957 ed.).

46. See Professor Grant Gilmore's recent suggestive, but incomplete, appraisal of the springs of realism: Gilmore, Legal Realism: Its Cause and Cure, 70 Y $\mathrm{ALE}$ L.J. 1037 (1961).

47. Cardozo, supra note 44, at 8-9.

48. Llewellyw at 12, 38, 49, 184-86. See J. Frank, If Men Were Afgels ch. xii (1942) ; Frank, Courts on TrIal 405-07 (1949).

49. Clark, supra note 43. 
search for "neutral principles," and the hue and cry for the "maturing of collective thought." 50

Perhaps the recent essay by Dean Erwin Griswold of Harvard is the zenith of what we may call the "New Quest for Certainty." The learned dean's image of law in this piece differs from Llewellyn's flexible and dynamic picture. ${ }^{11}$ Griswold disparages and hopes to limit judicial creativity, because he identifies it with the freedom to make law, ${ }^{52}$ while Llewellyn extols creativity and extols it all the more because he has separated it from this freedom. Nevertheless, Griswold shares with Llewellyn the desire for certainty; and he too rejects utterly the intrusion of judicial subjectivity on the process.

Griswold and others seem to us to be developing a new mythology of the judicial process to replace the myth destroyed by the realists. And even Llewellyn has, we fear, joined in this search for objectivity. His is a grander view of the sources of certainty, one with which it is certainly easier to live than that of the others. Nevertheless, it is a vision purchased at the price of omitting a crucial aspect of the judicial process as it really is. The omission, we submit, is dangerous.

\section{The Dangers of Illusive Certainty}

This belief in judicial objectivity and "neutrality," or in the ability of an institutional-traditional complex to control all aspects of judicial subjectivity, can be questioned on many grounds. Its philosophical underpinnings are doubtful; it springs from a belief that there can be objective knowledge, a belief which many would question. ${ }^{53}$ Such considerations, however, are beyond the scope of the review. But there are other objections; practical, everyday work-

50. Griswold, Foreword: Of Time and Attitudes-Professor Hart and Judge Arnold, 74 Harv. L. REv. 81, 88 (1961) ; Hart, The Time Chart of the Justices, 73 Harv. L. Rev. 84 (1959); Wechsler, Toward Neutral Principles of Constitutional Laze, 73 HARv. L. REv. 1 (1959). But see Mueller \& Schwartz, The Principle of Neutral Principles, 7 U.C.L.A.L. REv. 571 (1960) ; Miller \& Howell, The Myth of Nentrality in Constitutional Adjudication, 27 U. CHI. L. Rev. 661 (1960) ; Henson, A Criticism of Criticism: In re Meaning, 29 FoRDham L. Rev. 553 (1961). Compare L. Hand, The Bili of Rigrts 73 (1958), quoted in Clark, supra note 43 , at n.60.

51. Griswold, supra note 50 , at 88.

52. Id. at $93 \mathrm{n} .48$.

53. See Frank, Modern and Ancient Legal Pragmatism-John Dewey \& Co. vs. Aristotle, 25 Notre DaMe LAw. 207, 460 (1950). Of course the problem arises as to other disciplines, perhaps notably history. See FranK, Courts on Triar 37-40 (1949) ; FraNK, FATE AND FREEDOM 11-63, 76-84, 334-36 (1945). Reviewing three recent books of historical criticism, Professor David M. Potter, lately Coe Professor of American History at Yale, now of Stanford University, says in The Historian's Subjective Art, The Nation, vol. 193, no. 6, 123-25 (Sept. 2, 1961):

Until two or three decades ago, it was the dogma of professional historians that an objective reality called "history" could be extracted from manuscripts and archives by applying precise "scientific" rules of historical method. According to this dogma, any two persons applying the rules correctly would arrive at an identical result, and 
ing objections, that must be mentioned, for they go to the heart of the entire effort to create a new objectivity and neutrality, with or without the elaborate mechanisms of The Common Law Tradition.

These new concepts of judicial objectivity, untempered by recognition of the limits of human knowledge, all contribute to an illusion which hides the real machinery of the judicial process from its observers and its participants. How harmful is all this? May the book under review be simply dismissed as an intellectual joy ride of a brilliant mind? Llewellyn's impact on the legal profession, and particularly on its judicial branch, is too powerful to permit discount of its effect so easily. We are constrained to conclude that there are positive losses from his approach which cannot be overlooked.

Thus it is obvious that the lacuna we have noted in his analysis throws out of kilter the elaborate machinery he has erected for predicting the outcome of appeals and for thus aiding lawyers to reach proper decisions as to review tactics. If predictive analysis is to omit the decisive influence in the new case (where predictability would be most useful) of the judicial bias or code of personal values, then the results, as experience demonstrates over and over, are to the last degree dubious. This is a practical consequence of immediate and general scope. But the issue goes deeper and involves one's basic attitude toward law and its administration here in America in the year 1961.

Let us note the probable reactions of groups presumably most affected by a view of the law which overemphasizes certainty. There are the litigants, the lawyers, the judges, the authorities who select judges, and the law schools. Perhaps the lawyers will suffer least from the danger of false assumptions; those who regularly and assiduously study the personalities and idiosyncracies of individual judges, jurors, arbitrators, agency members, and in fact all types of adjudicators are probably too sophisticated to be greatly misled. Even with them, however, there is some danger that their tactical feel for the case may be warped or impaired. Perhaps also one need not worry about the effect on

therefore criticism was directed to questions of method, rather than to the men who applied it, and to the historian's way of authenticating data rather than of interpreting it.

But it is now more than thirty years since various historical relativists like Benedetto Croce, Charles A. Beard and Carl Becker overthrew the ascendancy of "scientific" history by showing how much selectivity enters into the historian's choice as to which items of data to use, and how much subjectivity is involved in his choice among alternative ways of interpreting them....

Literary criticism, legal criticism, musical criticism, are not expressed in the same medium as the work which they criticize, and are therefore not necessarily subject to the same limitations, but historical criticism is. As a consequence, history remains peculiarly caught in its own convolutions, and the discovery of a vantage point from which to take a truly detached view of historical writing remains one of the unfulfilled goals of the realm of learning.

We opine that whatever the situation as to music and letters, the compliment implied as to legal criticism is hardly deserved. 
litigants on the ground that it is their fate to be lulled into something approaching contentment by the assurance that law is not something contrived by human minds. For our part we are not sure that this rather popular view as to what is good for litigants is sound; we believe we can see more positive gains in a realistic policy of frankness with litigants, particularly with modern business, where litigation is a normal part of operation. But we must confess to a lack of data here to assess positive gains and losses. A third group unlikely to suffer permanent damage is that of the law schools-the students, the law review editors, and the professors. Assumptions of objectivity and neutrality will give them something to chew upon, and write about, particularly in defense of favorite or favored judges; but the spirit of skeptical inquiry inspired in part by Cardozo himself is too deeply entrenched in the schools to capitulate easily to an illusive certainty or will-o'-the-wisp objectivity.

No, the real danger as we see it is with the judges and those who select them, for blindness as to adjudicatory realities here may have serious consequences.

For the judge the consequences are twofold. First is the danger created by a false faith in judicial objectivity. If judges are easily convinced that they possess the key to objectivity, or a sixth sense for right and justice, will they not gain a false confidence in their own conclusions-conclusions that are in fact based on the humble stuff of subjective preference? Cardozo knew the inevitable impact of subjectivity; and he reports that it filled him with awe whenever he stumbledor leaped-into the heart of legal darkness where the lamps of precedent and of the common law tradition flicker and fade: "What am I that in these great movements onward, this rush and sweep of forces, my petty personality should deflect them by a hairbreadth ?" 54 He recognized that judges must struggle to transcend bias and prejudice. If, however, a judge is convinced that he possesses a special sense of things, which can lead to the one right rule, or that the human stuff he shapes and forms is "neutral" and "objective," will that judge struggle quite so hard? That, we submit, is a paramount danger of too quick a grasp at certainty.

But there is the reverse side of the coin, for an unwillingness to face the responsibility of judicial freedom in the name of a spurious objectivity may also cripple the exercise of creativity. Judges are the "naif, simple-minded persons" whom Holmes visualized; and they naturally like to clothe their pronouncements in perdurable terms. ${ }^{55}$ This may often be harmless; it is not, however,

54. Cardozo, op. cit. sutpra note 32 , at 172 .

55. "Judges prefer a formula-for that is what it is-that they merely declare the law and do not make it." RadclifFe, THe LAW AND the CoMpass 38-39 (1960), quoted in Clark, op. cit. supra note 43. 'Even when a significant decision 'makes judicial history,' it is 'not the judge who speaks, but the law which speaks through him.' This stage play is almost a necessity; jurists, whose occupation holds far more than its proper share of thankless tasks and dirty work, are more comfortable in having authorities with which to support their decisions, and the prestige of courts is strengthened by a recourse to 'the law' with which 'to beautify what may be disagreeable to the sufferers." "Hamilton, The Judicial Process, 8 ENcyc. Soc. Scr. 450, 454 (1932). For the reference to Holmes, see Holdres, Law and taE 
when it enables the judge to avoid the necessity of facing the consequences of his own decisions. Even a judge who satisfies Llewellyn's criteria of greatness has failed the parties litigant and his generation as well if he allows some compulsive cliché to press him to a merely traditional decision. An obvious case is that of supposedly strict construction for new legislation, with often a consequence that carefully considered remedial reform is aborted. A belief that there is no judicial freedom, that creation is controlled by a "tradition," will often lead to "creation" which is uniformly conservative; and a natural consequence of stress on certainty is to put a premium on judicial conservatism. It is an unfortunate weighting of the little, small dice of decision. There should be a sterner and more forthright exercise of judicial talent to look steadily and with balance to the consequences to be expected from the judicial act and to its effect as a precedent on the growth of the law. Escape from this hard task by reliance on neutrality and certainty to avoid forthrightness is itself a decision, albeit one of negation.

Examples of cases which force the judge willy-nilly to face the future, to make "new law," whichever way he decides, thus affecting not only the fortunes of the immediate parties, but also the course of decision for the future, are literally legion. ${ }^{56}$ In this area of the law it is a disservice to conceal the ebb and flow of doctrine and decision; and to falsify their consequences as being foreordained is to hamper the law's development by narrow precedents actually as novel to the litigants as would be the bolder ones which the situation demands. A false doctrine leads to a truncated opinion glorifying the hidebound approach. In the modern era so generally devoted to the development of legislation promoting the social welfare, the resulting limitations upon the scope of such statutes are a clear loss. It is of course the litigants for whom the new rights and privileges are devised who suffer. ${ }^{57}$ Here the result of judicial blindness is perhaps most obvious, but of course such an attitude permeates and falsifies judicial action widely and generally.

Court (1913), reprinted in Holnies, Collected Legal Papers 291, 295 (1921), and Lerner, The Mind and Fatth of Justice Holmes 387, 390 (1943).

56. We cite some recent illustrative examples-interesting, though far from atypicaltaken more or less at random from literally hundreds, here from the business field generally emphasized by Llewellyn: Perlman v. Feldmann, 219 F.2d 173 (2d Cir. 1955), cert. denied, 349 U.S. 952 (1955), reversing and remanding 129 F. Supp. 162 (D. Conn. 1952), a minority stockholder held to fiduciary responsibility to his co-stockholders; Drake Bakeries Inc. v. Local 50, 294 F.2d 399 (2d Cir. 1961), withdrawing 287 F.2d 155 (2d Cir. 1961) and affirniting 196 F. Supp. 148 (S.D.N.Y. 1960) by an equally divided vote, an agreement to arbitrate held to apply to a nonstrike clause of a collective bargaining agreement; Blau v. Lehman, 286 F.2d 787, 797 (2d Cir. 1960), cert. granted, 366 U.S. 902 (1961), trading partners of a corporate director held not liable for short-swing profits under $\$ 16(\mathrm{~b})$ of the Securities and Exchange Act of 1934, 15 U.S.C. $\$ 78 \mathrm{p}(\mathrm{b})$. The last decision goes back to Rattner v. Lehman, 193 F.2d 564 (2d Cir. 1952), relying on a strict construction of the statute. See Note, 61 Colum. L. Rev. 926 (1961) ; Note, 30 Fordhasr L. Rev. 178 (1961).

57. See note 56 supra. Compare FranK, Courrs on TrIAI 292-309 (1949), discussing "Words and Music: Legislation and Judicial Interpretation" and summarizing his views at 
The other area in which the ostrich approach to the judge's function may have serious and deleterious consequence is that of judicial selection and appointment. The phenomenon is of increasing importance as the process of selection takes on a wider scope and includes more persons in its scheme of operation. Now selection is rarely the act of a single executive or even party leader. It is a rite participated in by many, including, as a particularly novel and generally approved development, the action of one or more bar association groups. So federal judicial appointments now mean not sole action by the chief executive, but active co-operation of the various heads of the Department of Justice, together with the FBI, the senators, and from one to three or four bar groups on both the local and national levels. There are some substantial gains in the guaranties thus obtained of high professional character and reputation and, most strikingly, of high legal competence. But it has also a very obvious danger - even though all too generally overlooked-that of overstressing professionalism, of looking to the head exclusively, and not the heart. And the Llewellyn approach by its very nature unfortunately does not counteract, but indeed reinforces, this trend.

Thus the Missouri plan of judicial selection, pressed by the American Bar Association, here has Llewellyn's complete support, ${ }^{58}$ without notation of the dangers of a unique bias toward professional competence. Since in our economy the rewards of professional competence are, quite naturally and properly, the confidence of and employment by all the settled institutions of our society-the banks, the insurance companies, the mammoth business combines, and so on -the imbalance toward mere preservation of the status quo and notably its aristocratic elements is a potential danger for the courts. Thus if an executive can make his judicial choice only from a limited roster supplied him by a commission composed of the successful and conservative members of the community, then it is obvious that no one who deviates from the professional norm -labor lawyers, for example-need apply. ${ }^{59}$ So it is of truly vital importance that the inner convictions or bias of candidates for judicial appointment be appraised. Here is an almost unexplored, but quite decisive, aspect of the judicial function which deserves study and weighing at the beginning, not at the end, of a judicial career. It is true that some gestures in this direction have been disturbing rather than fruitful; while some Senate debates on candidates have occasionally reached a higher level, there has been also some

308: "Just as, perforce, the musical composer delegates some subordinate creative activity to musical performers, so, perforce, the legislature delegates some subordinate (judicial) legislation-i.e., creative activity-to the courts." See also Curtis, A Better Theory of Legal Interpretation, 3 VAND. L. REv. 407 (1950).

58. Llewellyn at 33, 34, 45 .

59. Not long ago the Association of the Bar of the City of New York had a judicial minstrel in the shape of Judge James Garrett Wallace, whose singing of legal lyrics-Those Appellate Division Blues, $A$ Mug in a Black Silk Robe, etc.-was the delight of Association 
tendency to stress the trivial, and even the malicious, ground of opposition. ${ }^{60}$ But that exists already and is unfortunately likely to continue; it should be counteracted by criteria of a higher level. So the need is great for developing a better technique, even for aid in formulating the proper questions to be used in testing judicial qualifications for a modern troubled age, than anything we have yet seen. Unfortunately the whole slant of Llewellyn's massive work is to discourage rather than accelerate the sophisticated exploration of this very real democratic need.

In this respect we should separate Llewellyn from the other writers with whom we have lumped him. Llewellyn's work is infinitely grander, richer, and more realistic than many of these recent articles calling for certainty. And it is for precisely that reason that Llewellyn may mislead judges where these other writers will not. The very brilliance of the book obscures the missing spire. The elaborate development of sense and situation, the constant stress on institutional, rather than "logical," controls, paint a convincing picture. Moreover, Griswold and the others are critical of the current operation of courts, and offer their principles as a needed antidote, not a description of how things are. Llewellyn, on the other hand, is talking of the is as well as the ought. $\mathrm{He}$ is defending the judges, not attacking them. He finds them working in the common law tradition, and working well. He attempts to document from today's cases his thesis of a creativity that transcends subjectivity, of growth without freedom. For these reasons his notions of judicial instinct, of sense and reason, may be all the more seductive to the highly flattered judge, and all the more likely to erode that "Pascalian" doubt that was a living principle to Cardozo.

nights. His song, The Old Missonti Plan, contained more than a modicum of social criticism:

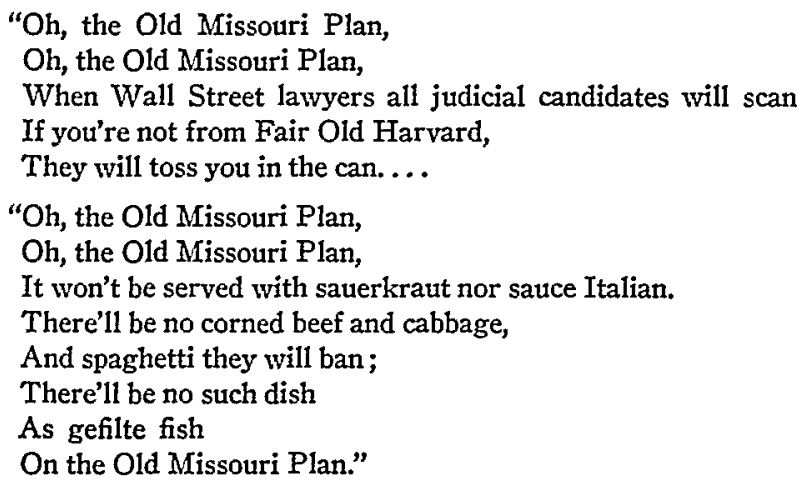

See Lyrics from "Wallace's Third Party"-A Minstrel Show 8, 9 (privately printed by "The Finest Printer in New York," 1948).

60. Thus some-though unfortunately not all-of the Senate debates in 1930 on the confirmations of Chief Justice Hughes and Judge Parker were of a high order. See extracts in Hicks, Organizatron and Ethics of the Bench and Bar 77-89 (1932). A recent trend toward punishment of sitting judges for their decisions is especially unfortunate. 
Significantly, when trying to pin down his own image of the impact of subjectivity on the judicial process, Cardozo turned to a message which Theodore Roosevelt had sent to Congress, a message which was highly criticized by the bar because it was said to ignore the "true, objective nature" of the judicial process:

The chief lawmakers in our country may be, and often are, the judges, because they are the final seat of authority. Every time they interpret contract, property, vested rights, due process of law, liberty, they necessarily enact into law parts of a system of social philosophy ; and as such interpretation is fundamental they give direction to all law-making. The decisions of the courts on economic and social questions depend upon their economic and social philosophy; and for the peaceful progress of our people during the twentieth century we shall owe most to those judges who hold to a twentieth century economic and social philosophy and not to a long outgrown philosophy, which was itself the product of primitive economic conditions. ${ }^{61}$

This is not only a shrewd description of the judicial process, but a wise hint for the correct exercise of the appointive power.

\section{In Summary-The Burden and Responsibility of Judicial Freedom}

We have now reached the conclusion of a rather long journey which has had its difficulties-as though one would try to breast Niagara-but has had its rewards in opening various new vistas of thinking about judges and their work. And we have paid the author our highest compliment, that of our most careful and diligent study of the product of his brain, as befits a notable achievement. If we have been led away from time to time from the author's main objective of portraying certainty in judicial adjudication, we can only excuse ourselves by noting that most of the fascinating bypaths are those his fertile mind has suggested. And it is perhaps a bit of fitting irony that the long journey upon which he has conducted us has led us to a divergent conclusion from his main thesis, namely a belief in the ultimate resilience of the American judicial process and to a positive affirmation of the creative power and force of so many of the individual judges whose work commands our attention. And that is as it should be.

We believe that our prior discussion has indicated our conception of what a great judge must be and do. But how close at bottom, notwithstanding different analyses, our conclusions and Llewellyn's tend to be may be shown by a convenient check he has provided, namely his lists of great judges. For he indulges in that natural by-product of any discussion of the judicial process. ${ }^{02}$

61. Id. at 171 .

62. Llewellyn's likes and dislikes are vividly stated. Thus on a title page he has an ingenious family tree tracing a direct line of descent from Holt and Mansfield to Learned Hand. The vividness applies also to writers; witness a seemingly growing doubt as to Judge Jerome Frank, who in earlier years had received enthusiastic praise and who has now become "a troubled man and almost great" and his most famous book, "queer." 
We would not quarrel with his list, though we might like to add some additional names to the roster. But we do suggest that one cannot understand his choices from any application of the main argument of his book, from expertness in applying the Llewellyn-Goldschmidt immanent law or sensing situation-sense or the like. On the surface such tests seem only those of good judicial craftsmanship, of ability to write well-capabilities now not typically unusual, particularly with the helping pens of highly trained law clerks. Why is the accolade denied to many men of convictions as sincere and pure as any of those included? (We often forget that those judges whose opinions we do not approve are as fine patriots as any of us.) The answer must be sought beyond this. And it seems not unclear when we turn to the generally accepted judgments of history.

Why is it that Marshall is placed at the very pinnacle of fame, while Taney is omitted? Why in a later era are Holmes, Brandeis, and Cardozo rated higher than their disagreeing opposite numbers or even than the middle-of-the-roaders, Hughes and Roberts? Is it not because they were creative innovators who fitted into what is now perceived to be the needs of the times? One might imagine a different judgment were Marshall and Taney to be transported to the modern era; and this might well be true even as to Holmes if his great dissents were to be separated from the events which called them forth. The truth is that the great judge is the one who has written for the future in those areas outside the daily grist where the future eventually becomes important.

Now we realize this is cold comfort to the beleaguered judge, who does not find it easy, or even possible, to anticipate "a doctrine which may be in the womb of time, but whose birth is distant"-to employ Learned Hand's descriptive phrase. ${ }^{03}$ Perhaps we have prescribed too Spartan a diet, pressing harsh realities beyond what will be readily accepted by a profession predisposed to the vague and mystical. But anything less can only lead astray, as we feel Llewellyn has led us astray. The judge is independent, and must exercise his independence. It is difficult to formulate principles to guide this judicial freedom or to provide simple maps through the maze of value-choices presented by any significant case. But it will not do to deny that the freedom exists or that the choices must be made. There are no immanent laws, easily grasped; no precise rules.

We do, however, agree with one fundamental premise of Llewellyn's book: that judicial creation is an inevitable and a vital part of our law, and that it should not be anarchical, unprincipled, or biased. We have sympathy for his goal of regularizing this creation, but we reject his method. Only by recogniz-

ILEWELLYN at 189, 220 n.24. Contrast this with somewhat extravagant praise of Professor Jerome Michael, who had a brilliantly logical mind, but hardly a realistic conception of practical court operation in the modern era. LlEwELLYN at $352,422 \mathrm{n} .46,511$; cf. Michael, The Basic Rules of Pleading, 5 THE RECORD 175, 192 (1950).

63. Hand, J., dissenting in Spector Motor Serv., Inc. v. Walsh, 139 F.2d 809, 823 (2d Cir. 1944). Since the Supreme Court vacated the judgment, 323 U.S. 101 (1944), Judge Hand appears to have been vindicated! 
ing the lonely responsibility of the judge as a legislator, and the inevitable subjective nature of his perception, can we hope to find ways and means of harnessing that subjectivity to the service of society, present and future. No man can stand at a judge's side as he makes his decision, but it might be possible to suggest how the background and experience which prepare a man for the task may be garnered. Our author here has a background of knowledge and belief which would make him a perceptive teacher of judicial independence; indeed The Common Law Tradition provides a wealth of material for such a study. ${ }^{64}$ Is it too much to hope that he will turn next to an examination of judicial freedom, and the springs of its exercise?

We have suggested that a fervent desire for certainty in the law has brought Llewellyn, and other legal thinkers, to embrace unquestioningly a faith in legal objectivity. It seems fitting, therefore, to close by quoting Cardozo once again: "As the years have gone by, and as I have reflected more and more upon the nature of the judicial process, I have become reconciled to the uncertainty, because I have grown to see it as inevitable. I have grown to see that the process in its highest reaches is not discovery, but creation; and that the doubts and misgivings, the hopes and fears, are part of the travail of mind, the pangs of death and the pangs of birth, in which principles that have served their day expire, and new principles are born." ${ }^{65}$ That profound truth apparently must be relearned, even by scholars as well as judges, again and again.

64. Since further printings of the present book will obviously be needed, we note certain errors in proof which may be easily corrected: p. $14 \mathrm{n.7}$, the citation of the Hamilton essay should be 8 Exc. Soc. Scr. 450 (1932); p. 45 n.39, the citation seems doubtful-should it not be to note 16, page 25 ?; p. 225 n.219, presentd for presented; p. 298, litle for little; p. 556, Index under Manton, add p. 327; cf. Prosser, 13 J. LEGaL Ev. 431, 432 (1961), suggesting rework for reword, p. 401, second line from botton of the page.

65. CARDozo, op. cit. supra note 32 , at 166-67. 